ISSN: 1641-4713; e-ISSN: 2081-1160

DOI: https://doi.org//10.36551/10.36551/2081-1160.2020.26.3-24

\title{
Xangô, Jurema e Umbanda: anotações sobre três formas de religião popular na região do Recife
}

\author{
Xangô, Jurema and Umbanda: Notes on Three Forms of Popular \\ Religion in the Recife Region
}

\author{
Roberto Motta \\ Universidade Federal de Pernambuco (UFPE), Brasil \\ ORCID iD: https://orcid.org/0000-0001-5683-0642 \\ E-mail:rmcmotta@uol.com.br
}

Recepción: 30.04 .2020

Aprobación: 13.10 .2020

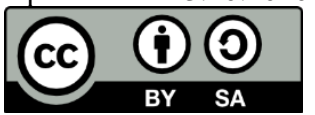

Resumo: Encontramos na área da cidade do Recife, no Nordeste do Brasil, três formas principais de religião popular, sincrética e mediúnica. O Xangô, influenciado pelas religiões da África Ocidental, pratica o culto aos orixás africanos, sincretizado aos santos do Catolicismo, através do sacrifício de animais e da festa, acompanhada pelo transe e pela dança. A Jurema gira em torno dos caboclos e dos mestres, que oferecem consolo e conselhos. A aspersão do consulente com fumaça de tabaco é rito frequente. Também característico é o consumo da jurema, bebida preparada com a raiz da árvore da jurema. A Umbanda, além de entidades sobrenaturais que são especialmente suas, cultua as entidades do Xangô e da Jurema. Estas devem passar por um processo de "branqueamento". Supõe-se que sejam entidades primitivas, mas capazes de progredir através da doutrinação por espíritos evoluídos. Aí se encontra o vislumbre de uma atitude ascética, estranha ao Xangô e à Jurema. De acordo com nossos cálculos, Xangô, Jurema e Umbanda compreendem, respectivamente, $30 \%, 60 \%$, e $10 \%$ de uma membresia de 150.000 pessoas. Aí não estão incluídos simpatizantes e frequentadores avulsos. O processo ritual é um campo de batalha socioantropológico. Transe, festa, dança ligam-se à organização e ao poder dentro dos grupos de culto e a concepções abrangentes de desenvolvimento pessoal e coletivo.

Palavras-chave: Recife, religião popular, sincretismo, xangô, sacrifício, festa.

Abstract: There are, in the area of Recife, in Northeastern Brazil, three main forms of popular, syncretic, and mediumistic religions. Xangô, influenced by West African religions, worships orishas, syncretized with Catholic saints, through animal sacrifices and feasts, accompanied by dances 
and trances. Jurema turns around mestres and caboclo spirits, who, through mediums, offer plenty of advice. Blowing tobacco smoke on needy persons is a frequent rite of Jurema. During special feasts, believers drink the jurema beverage, made from the roots of the jurema tree. Umbanda, besides spirits of its own, is ready to honor Xangô and Jurema spirits, if these are ready to accept Umbanda's ethos of spiritual purification. This attitude means the dawn of an ethic of asceticism and rationality strange to both Xangô and Umbanda. According to our estimation the three varieties have a combined membership of about 1500 people, $30 \%$ belonging to Xangô, $60 \%$ to Jurema, and $10 \%$ to Umbanda. Sympathizers and occasional visitors are not included in these figures. The ritual process is an anthropological battlefield. Sacrifice, feast and trance relate to structures of power within and without the cult groups and to encompassing conceptions of personal and collective development.

Keywords: Recife, popular religions, syncretism, Xangô, sacrifice, feast.

\section{OBSERVAÇÕES PRELIMINARES}

Grande parte da bibliografia sobre os cultos sincréticos e mediúnicos populares do Brasil trata do Candomblé da Bahia e do Rio de Janeiro e, em menor grau, dos seus equivalentes noutras partes do país.1 Entretanto, como veremos mais adiante, o Candomblé (com seus equivalentes regionais) é apenas uma dessas variedades e não necessariamente a que é mais praticada. O Candomblé coexiste, em todo o país, com outras formas de religião afro-indo-brasileiras, também mediúnicas, sincréticas e populares, que, de maneira talvez menos espetacular, têm atraído a atenção de estudiosos brasileiros e estrangeiros. ${ }^{2}$

Este artigo se concentra na cidade do Recife, ${ }^{3}$ capital do estado de Pernambuco, no Nordeste do Brasil, na qual, além do Candomblé, localmente conhecido como Xangô, duas outras formas de culto podem ser reconhecidas, Jurema e Umbanda. Os dados ora apresentados e discutidos resultaram de observação participante, completada por entrevistas, formais e informais, com membros desses cultos, além do exame crítico da bibliografia disponível. ${ }^{4}$

\footnotetext{
${ }^{1}$ Cf. Bastide, 1958, 1960, 1961, 1971; Carneiro, 1948; do Rio, 1951; Eduardo, 1948; Fernandes, 1937; Herskovits, 1943, 1955, 1958/1966; Leacock \& Leacock, 1972; Lima, 1977; Motta, 1977, 1982, 2015a, 2015b, 2015c, 2017; Motta \& Siuda-Ambroziak, 2019; Pereira, 1979; Pierson, 1945; Ramos, 1940; Ribeiro, 1952; Santos, 1976; Valente, 1955; Verger, 1957; etc.

${ }^{2}$ De Andrade, 1963; Bastide, 1960, 1971; Birman, 1983; Brown, 1977, 1985; Camargo, 1961; Carneiro, 1937; Cascudo, 1951; Fernandes, 1938; Fry, 1982; Ortiz, 1975; Pressel, 1973; Vandezande, 1975; Warren, 1970; etc.

${ }^{3}$ De acordo com a estimativa do IBGE (Instituto Brasileiro de Geografia e Estatística) para o ano de o recenseamento de 2019, a cidade do Recife possuía 1.645.727 habitantes. Na chamada "região metropolitana do Recife" esse número subia para 4054 866, de acordo com estimativa do IBGE para o ano de 2018.

${ }^{4}$ Minha tese de doutorado (Ph. D.), Meat and Feast: The Xangô Religion of Recife, Brazil preparada sob a orientação do Professor Robert F. Murphy, meu mestre, amigo e benfeitor, foi defendida, no Departamento de Antropologia da Columbia University, em 1984.
} 
Uso o termo mediúnico para denotar religiões nas quais os praticantes, ou pelo menos alguns deles, são habitualmente possuídos (conforme se acredita) por entidades sobrenaturais. Esta é uma definição mínima, que não implica em noções precisas sobre a natureza das entidades. Podem ser deuses, santos, encantados, almas de mortos, reis; podem ter origem africana, indígena, europeia ou asiática. A possessão é socialmente reconhecida por determinadas alterações, verbais e não verbais, no comportamento dos devotos. Certas palavras-chave, certos gestos, ou passos de dança, permitem que a congregação identifique a entidade ou as entidades que estão atuando ${ }^{5}$, ainda que muitas dúvidas possam subsistir sobre o seu status ontológico e sobre o lugar onde residem, quer neste, quer no outro mundo. ${ }^{6}$

A possessão algumas vezes se orienta para a consulta e o diálogo, enquanto outras vezes assume o caráter de um êxtase individual, que quase não faz uso de linguagem articulada. Pode constituir a experiência religiosa fundamental ou, mesmo que ocorra habitualmente, pode ter importância secundária, subordinando-se a outras práticas rituais. Este artigo, embora trate de possessão em sentido bastante amplo, não abrange nem o chamado "transe do Espírito Santo" das igrejas pentecostais, ${ }^{7}$ nem a frequente invocação e incorporação de espíritos, características do "Alto Espiritismo" ou Kardecismo, que não foram objeto do trabalho de campo em que se baseia nosso ensaio.

Tratamos aqui exclusivamente dos cultos mediúnicos mais populares. E, como "populares", queremos denotar (tentando evitar toda espécie de armadilhas teóricas), aquelas formas de religião que as investigações, empreendidas por nós ou por outros estudiosos, tenham empiricamente associado a estratos situados na parte mais baixa da escala socioeconômica da população recifense. Isto implica um nível de instrução formal pouco elevado entre os adeptos desses cultos.

Nem Xangô nem Jurema, podem, em sentido estrito, ser considerados "religiões do livro". Tais cultos, efetivamente, não possuem teologia explicitamente elaborada, sob a forma de artigos de fé e sistemas teológicos. ${ }^{8}$ Mas isto não quer dizer que deixem de possuir uma teologia implícita, envolvendo grande

\footnotetext{
${ }^{5} \mathrm{O}$ termo entidade, apesar de seu aspecto erudito, há muitas décadas tornou-se parte do vocabulário nativo e corrente das congregações.

${ }^{6}$ Salvo no caso de congregações particularmente influenciadas pelo espiritismo kardecista, ou por algum outro sistema teológico ou filosófico que lhe equivalha, não devemos esperar dos devotos definições exatas sobre a natureza do espírito ou da matéria.

${ }^{7}$ Em trabalho pioneiro, a socióloga francesa Marion Aubrée (1985) definiu as semelhanças e diferenças fundamentais entre o transe no Xangô e nas congregações pentecostais.

${ }^{8} \mathrm{O}$ caso da Umbanda exige ressalvas. Seus adeptos, frequentemente provenientes de uma baixa classe média, possuem maior acesso a sistemas de crenças elaborados, sobretudo, por autores ou praticantes que fazem um valente esforço para reinterpretar e "purificar" as práticas supostamente mais primitivas do Xangô e da Jurema.
} 
investimento intelectual. Tal teologia existe sobretudo na medida em que é exercida no processo ritual. ${ }^{9} \mathrm{O}$ que esses cultos possuem como teologia explícita e sistemática resulta largamente do trabalho de etnólogos e sociólogos, ${ }^{10}$ que retorna aos devotos através de canais orais e escritos, inclusive de farta literatura de divulgação, contendo detalhes sobre as divindades, prescrições para o jogo divinatório, rubricas rituais, etc. ${ }^{11}$

As diferenças fundamentais entre Xangô, Jurema e Umbanda são geralmente reconhecidas tanto pelos devotos como pelos estudiosos. Contudo, não existem fronteiras nítidas entre as três variedades. Centros intermediários ou aberrantes não são raros. Neste trabalho faço, acima de tudo, a descrição de tipos ideais. E tal descrição eu a farei segundo duas grandes categorizações. 1) A origem das principais entidades de cada culto; 2) o papel desempenhado pela possessão ou transe.

\section{XANGÔ}

O Xangô de Pernambuco, de maneira semelhante ao Candomblé da Bahia e do Rio de Janeiro, consiste basicamente no culto dos orixás ou santos. ${ }^{12}$ Estes apreciam acima de tudo sacrifícios de animais e ofertas de alimentos daí decorrentes. São estes os atos supremos do ritual. Em troca, os devotos recebem proteção sobrenatural em várias circunstâncias de sua vida, ligadas a emprego, finança, saúde, sexo, etc. Essas entidades e práticas têm raízes na África Ocidental, principalmente no sistema de ritos e crenças do povo iorubá. Sabe-se também que os filhos- e filhas-de-santo utilizam, como língua litúrgica, o nagô, que é uma forma dialetal e arcaica da língua iorubá. Sobre o assunto, existe vasta bibliografia, eminentemente representada pela obra-prima de Pierre Verger (1957), Notes sur le Culte des Orisha et des Vodoun.

\footnotetext{
${ }^{9}$ Para empregar o vocabulário dos antigos lógicos, diríamos que essa teologia existe in actu exercito, mas nem tanto in actu signato.

${ }^{10}$ Os pesquisadores funcionam como "ersatz" ou sucedâneos dos teólogos e tendem, por conseguinte, a adquirir o status de "doutores da fé".

${ }^{11}$ Esta bibliografia, do que conste a este pesquisador, nunca foi objeto de estudo monográfico. Pelo tempo em que começamos nosso trabalho de campo, essa literatura estava eminentemente representada pelos trabalhos de José Ribeiro, de origem pernambucana e chefe do terreiro Insan Egun Nitá, localizado em Jacarepaguá, Rio de Janeiro. Não era impossível que, em seu tempo, José Ribeiro, em número de exemplares vendidos, superasse qualquer outro autor brasileiro. Sirva de exemplo o seu O Jogo dos Búzios e as Grandes Cerimônias Ocultas da Umbanda (J. Ribeiro, 1963), que incorporava a caracterização dos orixás, tal como se encontrava em Pierre Verger (1957), e as regras da adivinhação pelo jogo dos búzios, tais como se encontravam em René Ribeiro (1952).

${ }^{12}$ Santos e orixás são termos praticamente equivalentes, tais como empregados pelos praticantes do Xangô, quando designam as entidades a que prestam culto. Doze orixás se destacam na área do Recife: Exu, Ogum, Odé, Obaluaê, Nanã, Oxum, Iemanjá, Xangô, Iansã, Oxalá, Orumilá e Ossanhe.
} 
Crenças abstratas importam pouco aos adeptos do Xangô, no qual tudo se subordina ao comportamento ritual. Se os orixás são deuses, ou heróis africanos de remota antiguidade, ou a tradução, para o nagô, de nomes de santos e de cerimônias do Catolicismo, ou se correspondem a espíritos desencarnados de certo nível de evolução, representam questões de muito interesse, capazes de serem respondidas de várias maneiras. ${ }^{13}$ São matéria de convicção pessoal que não precisam afetar o ritual. Dona Tonha era uma mãe-de-santo de grande prestígio, cujo terreiro eu por algum tempo frequentei. Além do seu Catolicismo, que demonstrava pelas missas que mandava celebrar pela alma de seu defunto pai-de-santo, estava persuadida de que sua Iemanjá era o espírito de uma mulher brasileira, que morrera poucos anos antes, com a idade de 35 anos, e cujo nome e biografia julgava conhecer detalhadamente. Mas, na medida em que as convicções de Dona Tonha não interferiam na sequência da liturgia, todos reconheciam seu status de ialorixá com impecáveis credenciais.

Conheci também pais-de-santo que podiam ser considerados como autênticos agnósticos. Ouçamos a alocução de Mário Miranda ${ }^{14}$, um dos mais famosos babalorixás recifenses da segunda metade do século XX:

A festa de Exu, vocês sabem, vai cair de hoje a quinze dias. Este ano a matança vai ser na noite do dia 22 de agosto. Vocês sabem que Exu é muito exigente. Vamos dar alguma coisa a ele. Muita gente me prometeu pintos. Vamos ver se a gente mata 300 ou 400 para Exu. Cuidado com batida de carro se vocês se esquecerem. Três pessoas me prometeram cabritos. Vamos ver se cumprem com a palavra. Iemanjá não pede nada. Ela sabe que não vai ser esquecida. Ela é diferente de Oxum, que está sempre com a mão aberta. Hoje à noite eu quero que a gente se lembre de Nanã. Sábado passado me deram essa imagem dela que vocês estão vendo. Ela é Santana na Igreja, em africano o nome dela é Nanã. Que pena que esse ano eu não pude fazer a festa dela do jeito que eu queria.

Agora vamos acender uma vela para afastar os inimigos. O povo é tão invejoso. Uma pessoa vai ao mercado e gasta 100 reais. Vem um amigo falso e diz 'como você está rico!'. Na outra semana aquela pessoa vai se achar feliz se tiver 50 reais pra gastar. Um rapaz é chofer de táxi. Ele está indo bem, mas aí é assaltado e deixado por morto dentro do canal. Mesmo assim o dono quer a parte dele, sem dispensar nem um tostão. Uma mulher compra um vestido novo, chega à cunhada dela e diz 'que bonito, onde você comprou?' Daqui a pouco o vestido se engancha num prego e se rasga.

É por isso que a gente tem que acender uma vela para o diabo. Sim, minha gente, a gente tem de agradar a Exu para ser feliz. Não, eu não acredito que o diabo existe. Os inimigos da gente são o diabo. Eu acredito que há três deuses nessa vida: Exu, o dinheiro e a polícia. Eu não acredito que haja vida depois da morte. Vou dizer como é o céu. Quando morre

\footnotetext{
13 Às vezes de acordo com o capricho momentâneo do informante ou com o que ele acha que corresponderá à resposta considerada como mais correta pelo pesquisador.

${ }^{14} \mathrm{O}$ pranteado Mário Miranda foi um dos meus principais informantes, durante minha pesquisa de campo sobre as religiões afro-brasileiras. Ele nunca, que eu saiba, publicou trabalho algum. A alocução que transcrevo aqui provém indiretamente de Miranda e diretamente das anotações que eu nunca deixava de fazer, muitas vezes em inglês, durante minha pesquisa.
} 
um homem bom, todo mundo fica triste e diz 'que pena, vamos rezar por ele'. Mas quando morre um homem ruim, todo mundo diz 'já morreu tarde, bota ele no caixão e enterra ele logo'. (Motta, 1984b, pp. 222-223)

Com pequenas variações, ouvi Mário pronunciar esta homilia, diante da congregação do terreiro, em três diferentes ocasiões. Ela contém uma mistura de surpreendente agnosticismo, de uma teoria do sincretismo como tradução linguística, de realismo trágico e de várias outras especulações. Por baixo de tudo, percebe-se a crença fundamental de que é preciso dar de comer aos santos.

Como falta à sua religião uma teologia explicitamente sistematizada, o povo-de-santo está pronto a levar em conta muitas espécies de explicações para as suas práticas. $\mathrm{O}$ sincretismo pode ser interpretado como uma dessas explicações. O Xangô muitas vezes se exprime ou se traduz em vocabulário católico. O espiritismo kardecista pode representar papel semelhante, como é também muitas vezes o caso da terminologia da Antropologia e da Sociologia. Estas disciplinas, sistematizando crenças e ritos, tornam-se úteis aos devotos em busca de autocompreensão.

Acreditamos que poucos autores entenderam tão bem o sistema de crenças afro-brasileiro como o historiador e etnógrafo norte-americano, Donald Warren Jr., cujo artigo, do qual extraio a seguinte citação, é uma dessas obras-primas da bibliografia afro-brasileira, da qual poucos ouviram falar e, ainda menos leram.

As religiões nativas da África Ocidental são tribais, isto é, não são ecumênicas ${ }^{15} \mathrm{e}$, ainda mais importante, não têm qualquer pretensão de exclusividade. [...] A religião era simplesmente um elemento da situação em que se encontravam no Brasil. [...] O Africano não culpou os santos católicos pelo seu cativeiro. [...] Os escravos fugidos ou rebeldes, inclusive os quilombolas de Palmares, não viram razão alguma para repudiar o Cristianismo nem ou para conservar apenas seus deuses tribais (Warren, 1970, pp.157-158).

Para empregarmos uma terminologia inspirada em Max Weber, o ritual do Xangô, orientado para o sacrifício de sangue, possui um caráter marcadamente "sacramental", na verdade mágico. Os ritos não apenas produzem, "ex opere operato", simplesmente por terem sido corretamente executados, alguma forma de graça, carisma ou bem-estar físico ou espiritual, como também, em termos estritos, não requerem atitudes internas ou disposições de caráter ético. A religião do Xangô de modo nenhum valoriza asceticismo e racionalidade. Os devotos possuem conhecimento inato dos grandes princípios éticos como, por exemplo, aquele que diz "não faças aos outros aquilo que não queres que te façam". Mas a religião do Xangô e assemelhadas não se preocupam com a imposição de pre-

\footnotetext{
${ }^{15}$ Este termo possui aqui o sentido de "universal", como no grego de que se origina.
} 
ceitos aos seus devotos, embora imponha regras de pureza ritual, bem como certo número de prescrições dietéticas. Diríamos que tais religiões são acima de tudo religiões de "observância" de determinados preceitos, inclusive, e mesmo principalmente, relativos ao oferecimento de sacrifícios. O Xangô consiste, acima de tudo, num sistema contratual de trocas entre os santos e os devotos. O que importa é a capacidade de fornecer os artigos previstos pelo contrato: sacrifícios para os santos, proteção para os devotos.

Os orixás estão longe de serem os únicos beneficiados com os sacrifícios. É verdade que possuem o monopólio do sangue até a última gota, derramado, sobre os "assentamentos". ${ }^{16}$ Além do sangue, colocam-se aí alguns órgãos vitais (fígado, rins, coração, pulmões, fígado, rins, baço e outros) para que os santos disponham deles como melhor lhes parecer. São os chamados axés. Entretanto, nas fases mais avançadas do processo iniciático, o sangue é também diretamente escorrido na cabeça dos devotos. O restante, compreendendo sobretudo as carnes vermelhas (o chamado eran) dos animais sacrificados, é distribuído, de acordo com determinados princípios de etiqueta e prioridade, com os membros do terreiro ${ }^{17}$ e com eventuais convidados ou beneficiados. Tudo isto confere ao Xangô um caráter muito prático, fazendo com que desempenhe papel não negligenciável na vida econômica da cidade. (Motta, 1977, 1984b).

A dança e o transe do Xangô possuem grande visibilidade. São, portanto, o que mais impressiona os assistentes. E isto tanto mais porque os sacrifícios de sangue nunca são executados em público, porém sim no pegi, a capela onde se guardam os assentamentos dos orixás, de permeio com estampas e imagens de feitio católico, representando os santos da Igreja que correspondem aos orixás. Sutis movimentos de dança são executados durante muitas cerimônias, inclusive durante os sacrifícios. A etiqueta do culto requer também que aquele ou aquela que oferece o sacrifício caia em transe de possessão pelo orixá a que oferece o sacrifício.

O transe nesse momento é um êxtase, durante o qual o devoto recai na sua identidade mais profunda. $\mathrm{O}$ transe, mesmo quando ocorre no meio de muito canto e muita dança, possui marcado caráter de êxtase. Enquanto dura, as faculdades cognitivas e afetivas do devoto, do filho-de-santo ou filha-de-santo, como são denominados os adeptos do Xangô e de cultos afins, ficam saturadas pela

\footnotetext{
${ }^{16}$ Os assentamentos, na terminologia do Xangô, são as pedras e metais, com determinadas dimensões, formas e cores, nos quais é instalada a presença e a força dos orixás. São eles (otás em nagô, embora o termo pareça derivar do português altar) que constituem os recipientes primários dos sacrifícios.

17 Termo usado normalmente para designar os santuários ou conventos do Xangô, compreendendo minimamente capela, cozinha, terraço de dança, além da residência, pelo menos, da família do sacerdote (babalorixá, pai-de-santo) ou da sacerdotisa (ialorixá, mãe-de-santo).
} 
força e pela irradiação da divindade. ${ }^{18} \mathrm{O}$ uso de conceitos e palavras, salvo por algumas exclamações em lingua nagô, ficam suspensos durante esse estado de arrebatamento.

O processo de consulta e adivinhação está normalmente associado ao jogo dos búzios ${ }^{19}$, durante um encontro particular entre o consulente e o adivinho, que normalmente é, ou tenderá a ser, em consequência da consulta, o pai- ou a mãe-de-santo daquele ou daquela que consulta. $\mathrm{O}$ aconselhamento através do jogo dos búzios é, portanto, o meio normal para que o devoto venha a saber qual é o santo dono de sua cabeça, isto é do mais profundo centro de sua identidade. Mas também para que o consulente possa informar-se sobre outros santos, que podem, por diversos motivos, estar reclamando sacrifícios. E serve ainda o jogo para que o devoto receba sugestões, enviadas do alto, sobre como devem ser resolvidos estados de necessidade devido a pobreza, doença e contrariedades diversas. Exclamações eventuais durante um transe, mensagens oníricas ou outras formas de revelação individual, só são consideradas válidas se confirmadas pela consulta aos búzios. No Xangô, como na Igreja Católica, o carisma pessoal nunca toma o lugar da autoridade hierárquica.

O sacrifício, como já assinalamos, é um rito íntimo, ao qual comparecem, além dos ministros que vão rezar e matar, o sacrificador, chamado "dono do ebó" na terminologia dos terreiros, pessoas de sua próxima família ou de sua próxima amizade e algumas pessoas de maior prestígio no terreiro. ${ }^{20}$

Os grandes sacrifícios, que ocorrem normalmente durante o dia, são completados pela festa, que ocorre normalmente durante noite. ${ }^{21}$ A festa, a dança, o transe $\mathrm{e}^{22}$ correspondem a momentos de identidade que não podem ser exaustivamente explicados em termos de função ou de qualquer gênero de utilidade, social ou econômica. Gestos sem sentido, transe aparentemente inútil, expressam aquilo

\footnotetext{
${ }^{18}$ O termo "xangozeiro", embora muito empregado, pode ter conotações pejorativas. Desde data ainda recente, tem predominado, em ambientes de pesquisadores, a forma xangozista.

${ }^{19}$ Os búzios, jogados normalmente dezesseis de cada vez, podem cair "abertos" ou "fechados". A proporção entre uns e outros possui significado oracular. Seria como se se arremessassem dezesseis moedas de uma vez e se contasse a proporção entre caras e croas. Os búzios são de fato as cascas de um molusco, Cypraea Moneta, que tinha valor de moeda, até bem entrado o século XX, em países da Ásia e da África Ocidental.

${ }^{20}$ Acontecia também que o pesquisador fosse admitido a presenciar esse ritual, o que era para mim uma grande distinção. Aconteceu-me também, duas ou três vezes, que eu patrocinasse algum sacrifício por amor à observação participante.

${ }^{21}$ Tratei expressamente do contraste, mas também da complementariedade, entre sacrifício e festa, em Motta 1984b.

22 "She hangs from the cheek of night like a rich jewel in an Ethiop's ear" (Shakespeare, Romeu e Julieta, ato 1, cena 5).
} 
que constitui o supremo objetivo de todas as religiões. É o duelo em que a vida luta contra a morte e a vida devora a morte. ${ }^{23} \mathrm{E}$ aqui estamos diante da oposição entre ser e nada, vida e morte. A consciência da mortalidade, a incerteza do precário e do contingente, superam-se pela fusão com a substância imperecível dos deuses. Agora, no meio de tanto esforço e tantas lágrimas, com os desejos de nossos corações, com a alegria de termos vivido até o dia da nossa festa, por um momento somos aquilo que somos. Cantamos e esboçamos os movimentos da dança que detém o tempo e derrota a morte.

\section{JUREMA}

A Jurema da área do Recife lida com um número indefinido de espíritos, que se enquadram sobretudo em duas categorias: mestres e caboclos. Ambos os termos podem ser interpretados de várias maneiras. Mestre, como assinala Mário de Andrade, ao tratar explicitamente da Jurema ou do Catimbó ${ }^{24}$ do Nordeste Oriental, parece ter tido a conotação original de perito na arte da cura. ${ }^{25}$ A Jurema, efetivamente, se encontra muito orientada para a prática da medicina mágica. ${ }^{26}$ Mas mestres e mestras, da "direita" ou da "esquerda"27, ocupam-se, além de cura,

\footnotetext{
${ }^{23}$ Pedindo licença por estas alusões rebuscadas, lembramo-nos aqui da "sequência" do domingo de Páscoa na liturgia romana: "Mors et vita duello conflixere mirando; Dux vitae mortuus regnat vivus", retomada por J. S. Bach na cantata BWV4 também para o domingo de Páscoa "Es war ein wunderlicher Krieg da Tod und Leben rungen; das Leben, das behielt den Sieg; es hat den Tod verschlungen; wie ein Tod den andern frass, ein Spott aus den Tod ist werden".

${ }^{24} \mathrm{O}$ termo Catimbó continua a ser usado na área do Recife. Mas possui conotação fortemente pejorativa.

${ }^{25}$ Mário de Andrade escreve que os catimbozeiros são "chamados de mestres, que é a usança tradicional portuguesa; Cândido de Figueiredo dá mestre com o sentido antiquado de médico para Portugal, acrescentando apenas que em Macau e no Ceilão a palavra significa curandeiro; mas que os feiticeiros se chamavam de mestres também em Portugal o prova um manuscrito de 1630" (de Andrade, 1964, p. 33).

${ }^{26}$ A medicina popular tem passado por acentuado processo de secularização nas últimas décadas do século XX e primeiras do XXI. Embora se possa concluir que a demanda por sistemas alternativos de caráter religioso tenha diminuído, ainda se está longe do desaparecimento desses sistemas, se é que isto jamais virá a acontecer.

${ }^{27}$ Em teoria o mestre que trabalha para a "direita" visa o bem das pessoas. Tal mestre me ajudará, por exemplo, a obter emprego numa universidade. O mestre da "esquerda" poderá encarregar-se de um "trabalho" visando explicitamente o mal de alguém, podendo ser invocado para que me desembarace do rival que cobiça o mesmo emprego. Os escolásticos, repetindo Aristóteles e, com certeza, uma sabedoria de muitas épocas e muitos povos, diziam simplesmente "corruptio unius est generatio alterius" ou, em termos ainda mais simples, o ganho de um é a perda de outro. E por aí se percebe como é sutil a diferença entre trabalhos de direita e trabalhos de esquerda. Entre todos os povos de todas as épocas, não é fácil conciliar o princípio da geração / corrução, com a "regra de ouro", que que nos proíbe de fazer ao outro o mal que não desejamos para nós ou, em forma positiva, que nos
} 
com muitos outros assuntos, ligados a saúde, amor, sexo, finanças, trabalho, etc. O termo "caboclo", originariamente, podia possuir várias acepções. Significava índio e, mais ainda, mestiço de índio e branco. Na prática, veio também a adquirir o sentido de homem do povo, o plebeu sem nenhuma pretensão social. Na Jurema, tal como a conheci, os caboclos possuíam referência a uma vaga identidade indígena, simbolizada pela mímica do arco e da flecha. Nos cultos sincréticos do Maranhão e da Amazônia, o sentido de "homem do povo" parece melhor conservado. ${ }^{28} \mathrm{Na}$ prática recifense, das últimas décadas do século $\mathrm{XX}$ e primeiras do XXI, as duas categorias têm se distinguido com bastante clareza. Há diferenças evidentes entre mestres e caboclos na gesticulação que acompanha a dança e o transe. Mas tal não foi a situação sempre e em toda parte. Segundo o relato de Oneyda Alvarenga (1949), as duas categorias ainda eram susceptíveis de confusão em Pernambuco e Paraíba. E, efetivamente, vamos encontrar, para o centro de Catimbó de Luís Gonzaga, um Mestre Caboclo Tupi (Alvarenga, 1949, p. 36), no meio de muitos outros mestres e mestras. Também para o Catimbó de Manuel Laurentino, de Itabaiana, na Paraíba, nota-se idêntica fusão, registrando-se Mestre Antônio Caboquinho da Jurema, Mestre do Caboco Danié, de permeio com Mestre Malunguinho, Mestre Zé Pilintra, Mestre Antônio da Cidade da Jurema do Reis Salamão, Mestre Carlos, e muitos outros.

A Jurema é provavelmente a religião mediúnica mais antiga do Nordeste luso-brasileiro. Uma sucessão de documentos, alguns deles reproduzidos por Vandezande (1975), indica que tem sido continuadamente praticada, em alguma forma, desde o século XVI, principalmente em "aldeias" de índios, de onde se espalhou, atingindo as grandes cidades da região. Os Juremeiros têm consciência da origem índia ou cabocla do seu culto. Mas, se as raízes indígenas são inegáveis, não são menos evidentes as fortes influências ibérica e africana, tanto na origem de muitos espíritos, como nos estilos de música e de dança.

A liturgia da Jurema, se comparada à liturgia do Xangô, é bastante simples. Consiste na invocação de um mestre (Carlos, Bom Florá, Inácio, Major do Dia, Castelhano, Zé Pilintra, Maria do Acais, Laurinda, Luziara, Paulina, Maria Padilha, etc.) ou de um caboclo (João da Mata, Jurandir, Pena Branca, Jacira, Jandira, Rei Canindé, Rei de Urubá, Rei Tamandaré, etc.). E, quando o espírito se incorpora no médium, em solicitar-lhe conselho sobre algum problema

ordena decididamente fazermos ao outro o bem que gostaríamos que nos fizessem.

${ }^{28} \mathrm{Ou}$ parecia, quando de minha pesquisa, tanto de campo quanto bibliográfica. Sobre o assunto, vejam-se Motta 2005, dos Santos 1995 e esta outra obra-prima que pouquíssimos leram, que é, sobre o Batuque de Belém, o livro do casal Leacock, Spirits of the Deep (1972). 
urgente, relativo, como já assinalamos, a saúde, emprego, sexo, etc. Uma característica acintosa dessas cerimônias é o uso do fumo (estritamente proibido nos rituais do Xangô). Com efeito - e fenômeno semelhante pode ser observado me rituais ameríndios, ou de derivação ameríndia, em praticamente todo o Hemisfério Ocidental- a Jurema é eminentemente o culto do tabaco, fumado de cachimbos, charutos e cigarros. Quando baixam, mestre e caboclos, gostam de aspergir os consulentes com fumaça. Este é o mais simples e mais accessível de todos os rituais de cura. Outra cerimônia importante, mas menos frequente, é o consumo solene da bebida, também denominada jurema, que consiste, ao menos em teoria, na infusão preparada com a raiz da jurema preta $^{29}$ à qual se atribuem virtudes alucinogênicas. Mas minha experiência pessoal me diz que o efeito principal desse líquido se deve ao que na prática é o seu principal igrediente, a aguardente de cana, à qual se acrescentam alguns pedaços da raiz sagrada. ${ }^{30}$

$\mathrm{Na}$ Jurema, os espíritos gostam muito de dar conselhos. E nisto se encontra uma diferença marcada com o Xangô, no qual também se oferecem muitas receitas de magia terapêutica ou outra. Mas neste as receitas normalmente provêm da consulta aos búzios, praticada por pais e mães-de-santo devidamente consagrados. Na Jurema, os espíritos, incorporados aos médiuns, transmitem oralmente suas mensagens, falando em português popular e regional. Efetivamente, a possessão mediúnica da Jurema é um fenômeno eminentemente verbal, com muito pouco da intensidade, da força, do arroubamento do transe típico do Xangô. Neste, os orixás normalmente desdenham o uso de qualquer língua que não seja o nagô e, mesmo neste idioma, não costumam emitir mais do que algumas palavras-chave, mais, de fato, como exclamações do que como afirmações.

As congregações de Jurema se articulam de maneira bem menos formal do que as do Xangô. Os laços de dependência entre mestre e discípulo, na primeira, são bem mais frouxos do que o relacionamento entre pai e filho-de-santo no Xangô. Para empregarmos aqui alguns conceitos provenientes da sociologia da religião de Joachim Wach (1944), ${ }^{31}$ no Xangô o grupo de culto se articula em torno do sacerdote (ou sacerdotisa) e a comunidade dos iniciados, ${ }^{32}$ isto é, dos "filhos" e das "filhas", enquanto na Jurema se trata acima de tudo do mago e de sua clientela.

\footnotetext{
${ }^{29}$ Mimosa Hostilis Benth, de acordo com Vandezande (1975).

${ }^{30}$ Tratei especificamente da Jurema, sobretudo a partir do uso ritual da bebida assim denominada, em Motta 2005.

${ }^{31}$ Wach, por sua vez, é fortemente influenciado pelo capítulo VI, "grupos religiosos", de Economia e Sociedade de Max Weber (1978).

${ }^{32}$ Para não dizer "igreja", termo marcado pelas especificidades da teologia cristã.
} 
Ainda em comparação com os orixás do Xangô, mestres e caboclos da Jurema muito claramente desempenham o papel daqueles espíritos que Ioan Lewis (1971) denominava "periféricos". Isto é, espíritos que permitiam às pessoas, sem outros meios de escaparem à carência social e econômica que, até certo ponto, melhorassem sua posição através do prestígio e dos honorários que lhes podem resultar de suas habilidades mágicas e do próprio espetáculo da possessão. Os orixás, ainda na terminologia de Lewis, são muito distintamente espíritos "ancestrais", que, se não chegam a afirmar um sistema "central" de moralidade, pelo menos reforçam as estruturas de poder econômico e político associadas aos grupos de culto. As coisas se complicam porque, se o Xangô é indubitavelmente "central" em comparação com a Jurema, é "periférico" com relação aos sistemas teológicos e rituais das igrejas cristãs, principalmente do Catolicismo, com o qual tem mantido, como se sabe, um longo relacionamento sincrético.

A carreira de um Juremeiro chega ao auge quando consegue ir além da Jurema, fazendo-se iniciar no Xangô, mesmo se isto acarreta reversão ao estágio de um aprendizado muitas vezes prolongado. Vamos dar o exemplo de Amara. Ela trabalhava, em tempo parcial, numa pequena empresa de fabricação de chapéus, ganhando muito pouco. Mas também se ocupava (e suplementava sua renda) com sessões de Jurema, uma ou duas vezes por semana, em sua própria casa, situada num morro da periferia do Recife.

Grande destaque em seu panteão possuía o Mestre Zé Pilintra (que alguns qualificariam como "espírito zombeteiro"), com muita probabilidade a entidade com mais frequência invocada e recebida, no Nordeste Oriental. Pouco a pouco Amara se infiltrou no terreiro de Dona Alzira (um dos mais reputados do Recife ou mesmo do Brasil), localizado não muito longe de sua casa, porém bem mais próximo da planície. Amara não demorou a entender o que teria a ganhar se se fizesse iniciar no Xangô, sob a orientação de Dona Alzira. Suas credenciais religiosas e mágicas seriam muito reforçadas se conseguisse ser admitida na família ritual da ilustre ialorixá, adotando, com toda legitimidade, suas tradições e genealogias.

Para chegar a tanto, teve de economizar somas importantes, em grande parte provenientes de seus próprios clientes na Jurema. Precisou também superar, por parte de pessoas ligadas a Alzira, as objeções, relativas ao estabelecimento de um terreiro, potencialmente rival, na mesma vizinhança. Teve também de tolerar as insinuações, até por parte do seu pai-de-santo (neto carnal de Alzira), de que seu Oxalá (“o pai dos orixás, que mulher mais metida!”) não passava de um simples caboclo, uma espécie de impostor, capaz de fazer-se passar por entidades do mais alto nível hierárquico. Tudo isto e mais alguma coisa Amara teve de 
suportar, mas atingiu seu objetivo. Tornou-se uma filha-de-santo, habilitada a proporcionar assistência de melhor nível a sua congregação, com elevação proporcional de seus honorários e, no devido tempo, a iniciar seus próprios filhosde-santo, presumivelmente sob a supervisão de Alzira e do seu neto. ${ }^{33}$

Apesar dos diferentes espíritos que invocam, da diversidade com que estes se manifestam, o Xangô e a Jurema se assemelham na ênfase que atribuem aos aspectos mágicos da religião. Não propõem sistemas éticos abstratos a seus devotos, como já vimos a propósito do Xangô, e estão muito distantes dos critérios weberianos de asceticismo e racionalidade. ${ }^{34} \mathrm{Na}$ terminologia de outro autor famoso, Victor Turner, Xangô e Jurema enfatizam o ícone, bem mais do que o logos. "As religiões iconofílicas" - diz Turner- "desenvolvem sistemas rituais complexos e elaborados; os símbolos tendem a ser visuais e a exegese está ligada ao ciclo ritual" (Turner, 1975, p. 155). Notemos ainda que a importância atribuída à fala no transe da Jurema - bem como sua organização marcadamente mais informal - parecem acima de tudo derivar da pobreza que a impede de adotar a estrutura mais rígida do Xangô, o qual acentua a autoridade, o sacrifício, o transe de êxtase e a consulta aos búzios, proporcionada por pessoas para tanto especialmente consagradas.

\section{UMBANDA}

O termo umbanda pode ser utilizado com três sentidos diferentes. Tal como o empregamos neste ensaio, conota sobretudo a reinterpretação, a seu modo racionalizadora e, muito a seu modo, europeizante, das religiões populares sincréticas do Brasil. Trata-se, por assim dizer, de uma nova religião, indo-afro-brasileira no seu conteúdo, mas europeia, até mesmo francesa, na sua forma. Com este sentido, o termo é crescentemente entendido a partir da terceira década do século XX, sob a influência de autores que possuíam alguma erudição e bastante informação sobre o espiritismo codificado pelos trabalhos de Allan Kardec. Dentre estes, avulta Le Livre des Esprits (Kardec, 1857) com muitas edições em lingua portuguesa.

Noutro sentido, Umbanda conota tudo aquilo que, no domínio das religiões populares sincréticas difere das suas formas centrais, o Candomblé da Bahia e do Rio de Janeiro, o Xangô de Pernambuco e estados vizinhos, e o Batuque do Rio Grande do Sul. Seria, neste sentido, a designação das formas periféricas das religiões sincréticas, enquanto distintas das formas centrais dessas religiões.

\footnotetext{
33 Trato mais detalhadamente deste tópico dos últimos três parágrafos em Motta, 1984a.

${ }^{34} \mathrm{O}$ que não os impede de possuírem sua própria lógica e, portanto, de representarem, a seu modo, sistemas racionais.
} 
E, ainda noutro sentido, Umbanda, para todos os efeitos práticos, aplica-se não apenas às variedades mais europeizadas ou mais periféricas, mas a todo o domínio indo-afro-brasileiro. Neste terceiro sentido, o termo era muito empregado em meados da década de 1970, quando comecei meu trabalho de campo e minha longa convivência com essas religiões. Lembro-me, em terreiros, de perguntas e afirmações com o seguinte teor:

- "Ah, o senhor gosta da Umbanda?", era pergunta que eu ouvia em casas tradicionais do Recife e até de Salvador, para indagar meu comprometimento com os ritos ali realizados.

E, da mesma pessoa, cerca de 30 minutos depois:

- "Nossa seita não é de Umbanda"; "nossa nação não tem nada a ver com a Umbanda"; "este terreiro não é traçado com Umbanda".

Tais negações implicavam, a contrario, em outras tantas reivindicações de tradição, ortodoxia e ortopraxia. Os afro-brasilianistas conhecem a importância da "nação" no candomblé, no xangô e cultos análogos. Na Bahia e em Pernambuco ${ }^{35}$ prevalece a nação Nagô, muitas vezes denominada, na Bahia, Ketu. Em São Luís do Maranhão são famosas a Casa de Mina e a Casa de Nagô.

Todos os espíritos são bem-vindos à Umbanda, ${ }^{36}$ se se dispuserem a aceitar certas regras de reinterpretação. Os Umbandistas não fazem objeções a orixás caboclos, mestres, ciganos, ${ }^{37}$ pretos-velhos ${ }^{38}$, crianças, ${ }^{39}$ e diversos outros tipos de entidades, com a condição que aceitem o ethos do "desenvolvimento". Ora, tal ethos constitui uma das características essenciais da Umbanda. Trata-se de espíritos primitivos, que devem reconhecer seu atraso e necessidade de progredir. Sua humildade os redimirá. Tendo sido sujeitos à opressão, à exploração, à indigência, em vidas anteriores (os Umbandistas acreditam firmemente na transmigração das almas), são capazes de compreender, perdoar e consolar as fraquezas, as falhas e o arrependimento dos que padecem neste vale de lágrimas.

A Umbanda aceita e venera os espíritos do Xangô e da Jurema, porém os submete a reinterpretações que se assemelham a $\mathrm{m}$ processo de desmitologização.

\footnotetext{
${ }^{35}$ Para Pernambuco nos anos 1970 parecia-nos existir cinco nações principais: Nagô, Jeje, Xambá, Angola e Congo. A nação Nagô era de longe a mais numerosa. De fato, naquela década, Pernambuco passava por um acelerado processo de "nagôização", em parte devido ao prestígio do terreiro do Sítio, que reivindicava pertencimento a essa nação.

${ }^{36}$ Interpretada como movimento racionalizador e europeizante.

${ }^{37}$ Os ciganos e as ciganas são particularmente fortes nas artes divinatórias.

${ }^{38}$ Os pretos-velhos formam uma categoria de espíritos análoga às dos caboclos e dos mestres, embora inferiores a eles em popularidade. Tendo sofrido muito antes de subirem para o astral, os pretos-velhos acumularam muita sabedoria e se especializam na arte de consolar os seus aficionados.

${ }^{39}$ Há também, na Umbanda e cultos afins, espíritos correspondentes ao arquétipo da Traviata, isto é, da mundana do coração de ouro, que muito amou e muito sofreu.
} 
Iemanjá, por exemplo, vem a ser já não a deusa do Oceano, mas, como se exprimiu uma de minhas informantes, "nossa irmã Iemanjá, que nós conhecemos, estimamos e com a qual, de vez em quando, nós conversamos". Ogum não deixa de ser o santo guerreiro que combate o dragão da maldade, mas, depois de um longo processo evolutivo, compreendeu que o amor fraterno e, muitas vezes, a paciência constroem mais do que o ódio e a revolta. ${ }^{40}$

Essas entidades tornaram-se capazes de ensinar o bom caminho, ao mesmo tempo em que se dispõem a receber instruções de espíritos mais altos, ou até de simples mortais. A Umbanda, a seu modo, retoma o mito do "bom selvagem". É um movimento de volta à natureza, mas sujeito à restrição de que as eminentes virtudes dos selvagens só adquirem sentido integral num contexto de evolução cultural, através de muitos esforços, sofrimentos e reencarnações.

Mas há, neste movimento religioso, uma contradição interna. É uma síntese que tende a dissolver-se. Ou a Umbanda continua avançando na direção do Kardecismo, com referências ocasionais aos espíritos "primitivos", ou reverte ao Xangô e à Jurema, mesmo se um leve tempero evolucionista for conservado por alguns participantes.

Julgando pela frequência com que é mencionado pelos autores que o sucederam, Cândido Procópio Ferreira Camargo foi o príncipe dos umbandólogos brasileiros. Em seu livro Kardecismo e Umbanda (Camargo, 1961), este autor seguia um paradigma evolucionista, que não deixava de apresentar certa analogia com a sociologia histórica de Max Weber, tal como interpretada por Talcott Parsons.

Camargo queria reconhecer, nas duas formas de religião mediúnica do título do seu livro, a expressão, ao nível do sistema cultural do novo Brasil, industrializado e urbanizado. Em seus próprios termos:

Por paradoxal que possa parecer à primeira vista, as religiões mediúnicas (especialmente o setor mais próximo do Kardecismo) constituem uma das expressões do nosso relativo processo de racionalização e secularização. Certos traços característicos favorecem esse papel: capacidade de ser fonte de orientação para os indivíduos (substituindo a tradição e sua autoridade), aceitação de valores urbanos e profanos, busca de coerência explícita com a 'ciência' e a atitude 'científica', etc. (Camargo, 1961, p. xii).

Para Roger Bastide,

O espiritismo de Umbanda [...] corresponde à formação de uma classe baixa racialmente heterogênea [...] à tomada de consciência desta classe e à sua vontade de ascensão social no contexto de uma sociedade industrial concorrencial, do mesmo modo que marca a transformação do pensamento intelectual [sic] sob a influência de um ambiente marcado pela racionalização onipotente, pois esse espiritismo marca a passagem de um sistema simbólico a um sistema conceptual. Numa palavra e voltando ao nosso assunto específico:

${ }^{40}$ Tais opiniões, como vimos anteriormente no caso de Dona Tonha, não bastam para caracterizar a adesão à Umbanda, se não ocorrerem igualmente transformações no ritual e na organização do grupo de culto. 
o casamento dos deuses africanos e dos espíritos ameríndios é o reflexo ou expressão, ao nível da consciência religiosa da massa, das metamorfoses trazidas às estruturas sociais pela urbanização intensa e pela industrialização triunfante (Bastide, 2006, p. 219).

Diana Brown, é autora de alguns trabalhos de muita repercussão sobre a origem e desenvolvimento desta forma de religião. Sua interpretação é menos otimista que a de Bastide, como se percebe pela seguinte passagem:

O organizador do Primeiro Congresso de Religiões Afro-Brasileiras, realizado em Recife em 1934 foi nada menos que Gilberto Freyre, que também teve participação destacada na organização da primeira federação protetora desses grupos religiosos naquela cidade (Brown, 1985, p. 17). ${ }^{41}$

Mais adiante, nossa autora sustenta que

Artigos publicados no Jornal de Umbanda, em O Semanário e em muitas outras colunas e publicações da Umbanda, referiam-se à Umbanda como "uma religião brasileira", "Umbanda, Religião Nacional do Brasil", "Umbanda, ideal religioso para o Brasil”, com frequentes menções à temática desenvolvida por Gilberto Freyre de ser o Brasil o único produto de miscigenação e a Umbanda a única e verdadeira expressão religiosa dessa mistura (Brown, 1985, p. 30). ${ }^{42}$

A Umbanda, pelo menos a que Diana Brown denomina "Umbanda Pura" (Brown, 1985, p. 12) resultaria, portanto, de uma aliança na qual tomaram parte "as classes médias", Getúlio Vargas ${ }^{43}$ e Gilberto Freyre, este último aparecendo como o grande vilão da história.

$\mathrm{Na}$ prática ritual, a diferença essencial entre, de um lado, a Umbanda, do outro o Xangô e Jurema prende-se à menor ênfase atribuída aos aspectos mágicos ou, como diria o pranteado Victor Turner, iconofílicos, pela Umbanda, se comparada às duas outras formas de religião brasileira sincrética que aqui reconhecemos. Por outro lado, ocorre, na Umbanda, um considerável aumento dos aspectos verbais do ritual, através do diálogo (consulta, aconselhamento) entre os espíritos, falando através de médiuns, e os devotos que acorrem em busca de alívio e orientação. ${ }^{44}$

Nenhum grupo de culto pode ser reconhecido como autenticamente umbandista se dele não tiver sido eliminado aquilo que os reformadores encaram como sendo as monstruosidades e as abominações da idolatria. Assim é que a Umbanda

\footnotetext{
${ }^{41}$ Ambas as afirmações sobre Gilberto Freyre, neste parágrafo, devem ser interpretadas com muita circunspecção. O congresso, organizado, em 1934, por Gilberto Freyre, foi o primeiro Congresso Afro-Brasileiro, no qual muitos assuntos foram tratados, inclusive alguns que tangenciavam as religiões afro-brasileiras.

${ }^{42}$ Há bastante ambiguidade nesta passagem. Mas não cremos que, em nenhum lugar, Freyre, ao contrário do que Brown dá a entender, tenha afirmado "ser o Brasil o único produto de miscigenação" (a frase já é em si obscura), nem, muito menos, que a Umbanda seria a única e verdadeira expressão religiosa dessa mistura e, por via de consequência, a autêntica religião nacional brasileira.

${ }^{43}$ Getúlio Vargas foi presidente do Brasil, continuadamente, de 1930 a 1945.

${ }^{44} \mathrm{Na}$ terminologia de $\mathrm{V}$. Turner, o logos cresce na proporção em que diminui o icon.
} 
fundamentalista proíbe o uso do tabaco e da jurema (bebida) durantes as cerimônias. O vocabulário muitas vezes obsceno, bem como a gestuália imprópria, a que são afeitas algumas das entidades da Jurema, são também fortemente reprovados pelos umbandistas mais corretos. Mas nunca se deve desesperar do progresso. A doutrinação desses espíritos pouco evoluídos é da competência dos bons umbandistas.

Os umbandistas da estrita observância condenam a prática de danças rituais. Admite-se o canto, mas sem espalhafato e sem o acompanhamento de tambores e outros instrumentos musicais "primitivos" Finalmente a espinha dorsal do ritual do Xangô, isto é, o sacrifício de animais, é condenado como "selvagem" e eliminado sem remissão alguma, mesmo quando praticado em honra dos espíritos de antigos selvagens. Porém convém notar, a propósito de todas essas interdições, que, como os brasileiros gostam de dizer, "na prática, a teoria é outra."

\section{ORIGEM SOCIAL E RELIGIÃO}

Constitui um postulado implícito deste ensaio que, dentro de uma determinada sociedade, o fenômeno religioso não pode ser entendido sem levar em conta (parafraseando Tylor) as outras experiências, capacidades e hábitos adquiridas pelo ser humano como membro de uma sociedade. Com referência ao Xangô, nossa longa experiência de campo, reforçada por questionários escritos que aplicamos a considerável amostra de nossos cultistas, indicam que constituem uma plebe, composta de artesãos, pequenos lojistas e vendedores, pequenos funcionários públicos, pessoal subalterno de hospitais, costureiras, cozinheiros e garçons e, bem entendido, bastante pessoas desempregadas e subempregadas.

Convém destacar que o Xangô do Recife, bem como cultos análogos, é fenômeno eminentemente urbano. Não obstante suas raízes na terra dos Iorubás, o Xangô, em Pernambuco, não está associado a nada de rural. Tradições orais e documentos esparsos indicam, pelo fim do século XIX, a presença de terreiros no centro da cidade do Recife. A partir daí, no princípio do século XX, as congregações se transferiram, em grande número, para o vale do rio Beberibe, no nordeste da cidade. E esta, até o dia de hoje, constitui a grande reserva biológica e cultural dessa religião. Tudo indica a que o culto se originou entre pequenos artesãos e pequenos comerciantes, da origem sobretudo ioruba e fon, os quais, até o fim do século XIX, estiveram associados ao ativo comércio entre o Nordeste do Brasil e a costa ocidental da África.

Diferentemente do Xangô, a Jurema se enraíza em áreas rurais do Nordeste do Brasil (Alvarenga, 1949; Fernandes, 1938; Vandezande, 1975), sobre- 
tudo nos redutos onde por mais tempo se preservou a identidade indígena. Essas raízes, a que já aludimos, se expressam nas frequentes alusões dos juremeiros a aldeias indígenas, a lendas sobre cidades e reinos encantados, inclusive à mítica Cidade da Jurema. Há também fortes diferenças entre o estilo musical das toadas do Xangô e dos "pontos" da Jurema. Mas apesar de todas as diferenças nas suas origens e seus estilos, tanto o Xangô quanto a Jurema são religiões tradicionais dentro de uma sociedade tradicional. E, embora sejam religiões de pobres, não há nenhuma razão para que se conclua que são religiões de protesto em qualquer sentido da palavra. Ao contrário, tanto uma como outra exibem marcado conformismo social e econômico. ${ }^{45}$

Este princípio certamente se aplica ao Xangô e à Jurema, com a restrição, entretanto, de que os filhos-de-santo, ${ }^{46}$ lidando com o ambiente do Recife, demonstram um savoir faire bem maior que o dos juremeiros. O povo do Xangô é, por exemplo, muito mais hábil do que os juremeiros na manipulação de redes clientelísticas, com conotações políticas e econômicas.

Em oposição tanto ao Xangô como à Jurema, à Umbanda, pelo menos no nível da ideologia, está comprometida com um projeto de desenvolvimento cultural, social e político. Esta atitude corresponde com as origens sociais dos seus adeptos. Estes são muitas vezes recrutados em uma classe média proveniente dos setores mais modernizados da indústria e dos serviços da área metropolitana do Recife. Tais adeptos frequentemente residem nos bairros situados na zona oeste do Recife, onde também se encontram muitos dos centros de prática da Umbanda.

\section{SUMÁRIO E CONCLUSÕES}

\section{I}

Três variedades de cultos populares, sincréticos e mediúnicos podem ser identificadas na área da cidade do Recife, capital do estado de Pernambuco, no Nordeste do Brasil. São o Xangô, mais conhecido, fora do Recife, como

\footnotetext{
${ }^{45}$ Os resultados de minha pesquisa no Recife concordam plenamente com a pesquisa do casal Leacock, empreendida sobre o Batuque de Belém do Pará, uma forma de culto semelhante à Jurema do Recife. De acordo com os Leacocks: "Visto da perspectiva dos cultistas, o apelo do Batuque não é que prometa mudar o mundo, mas sim que os ajudará a viver neste mundo. [...] Os terríveis problemas que os pobres têm de enfrentar são parte deste mundo e a única esperança deixada aos homens é a de obterem apoio sobrenatural para lidar com eles" (Leacock \& Leacock, 1972, p. 36). O livro dos Leacocks é outra dessas obras primas, que pouquíssimos leram, sobre as religiões indoafro-brasileiras.

${ }^{46}$ Que podem ser também denominados coletivamente, sobretudo por pesquisadores, como povode-santo.
} 
Candomblé; a Jurema; e a Umbanda. De acordo com nossos cálculos, compreendem, respectivamente, $30 \%, 60 \%$, and $10 \%$ do total de uma membresia estimada em 150.000 pessoas. Neste total não estão incluídos simpatizantes e frequentadores avulsos.

\section{II}

Essas três variedades diferem em três aspectos fundamentais: 1) a origem das entidades sobrenaturais; 2) a presença ou ausência de sacrifícios de sangue; 3) a natureza e a função atribuídas ao transe.

\section{III}

O Xangô consiste essencialmente no culto dos orixás, ou santos, de origem principalmente iorubana. Essas divindades apreciam sobretudo oferecimento de sangue e carne de animais, através do ritual do sacrifício. Os devotos, segundo a crença, recebem proteção por parte dos deuses em matéria de saúde, emprego, prosperidade, amor, etc. O transe, de caráter normalmente extático, a dança e a festa são aspectos muito importantes do Xangô. Pais- e mães-de-santo desempenham o papel de intermediários entre os homens e os deuses e são também os ministros da adivinhação através do jogo dos búzios.

\section{IV}

O culto da Jurema gira sobretudo em torno dos caboclos e dos mestres. $\mathrm{O}$ transe na Jurema é eminentemente verbal. Mestres, caboclos e outras entidades respondem a perguntas e oferecem consolo e conselhos, além de sugerirem operações mágicas, sobretudo em caso de conflitos e disputas. A aspersão do consulente com fumaça de tabaco é um rito muito frequente. Também característico desta forma de culto é o consumo de uma bebida, denominada jurema, preparada com a raiz da árvore da jurema.

\section{V}

A Umbanda, além de entidades sobrenaturais que são especialmente suas, cultua, a seu modo, as mesmas entidades do Xangô e da Jurema. Porém estas devem passar por um processo de reinterpretação, que alguns intérpretes encaram como um processo de branqueamento. São vistas, pelos umbandistas, como entidades, na origem, primitiva, mas que se desenvolveram, graças à doutrinação que receberam de espíritos mais evoluídos, desencarnados ou encarnados. Podem agora, esses espíritos, contribuir para o desenvolvimento daqueles que os consultam. Aí se encontra o vislumbre de uma atitude ascética, estranha tanto ao Xangô quanto à Jurema. As congregações da Umbanda formam, em teoria, associações voluntárias e democráticas. Porém, na prática, o poder pessoal de líderes carismáticos, visionários, magos e curadores, sobrepõe-se com frequência ao progra- 
ma igualitário. Ao contrário dos juremeiros, os umbandistas, em regra geral, não se recrutam entre os que sofrem de fome crônica. E, diferentemente dos adeptos do Xangô, não se sentem atraídos por uma religião baseada em sacrifícios e banquetes. Comem em suas próprias casas e podem dar-se ao luxo de secularizar as refeições e desvalorizar os sacrifícios.

\section{VI}

A diversidade das religiões mediúnicas na área do Recife liga-se a fatores de ordem sociológica e histórica. Xangô e Jurema são marcadamente religiões de gente pobre, mas também religiões marcadamente conformistas. Seus adeptos apegam-se a uma concepção tradicionalista e estática da sociedade, que veem como praticamente imutável, ou, numa perspectiva por assim dizer maquiavélica, acham que quanto mais mudar, mais ficará como sempre foi. Tanto quanto podem, xangozistas e juremeiros tentam atingir posições de relativa vantagem dentro dessa sociedade, os primeiros tendo mais êxito, nesse empreendimento, do que os segundos. Os umbandistas aderem a um ethos de progresso indefinido e assim, querendo-o ou não, aderem também, nas versões mais ortodoxas desta denominação, a um certo paradigma de modernização. O processo ritual é um campo de batalha socioantropológico. Concepções, por vezes, muito sutis de sociedade, cultura e história encontram-se latentes na maneira em que se supõe que os espíritos se comuniquem com seus devotos. Transe, festa, dança ligam-se às estruturas de organização e poder dentro dos grupos de culto e a concepções abrangentes de desenvolvimento pessoal e coletivo.

\section{BIBLIOGRAFIA}

Alvarenga, O. (1949). Catimbó. Biblioteca Municipal.

Aubrée, M. (1985). O Transe: A Resposta do Xangô e do Pentecostalismo. Ciência e Cultura 37(7), 1070-1075.

Bastide, R. (1958). Le Candomblé de Bahia: Rite Nagô. Mouton.

Bastide, R. (1960). Les Religions Africaines au Brésil. Presses Universitaires de France.

Bastide, R. (1961). O Candomblé da Bahia: Rito Nagô. Companhia Editora Nacional.

Bastide, R. (1971). As Religiões Africanas no Brasil. Pioneira.

Bastide, R. (2006). O Sagrado Selvagem e Outros Ensaios. Schwarcz.

Birman, P. (1983). O Que É Umbanda. Brasiliense

Brown, D. (1977). Umbanda e Classes Sociais. Religião e Sociedade, (1), 31-42.

Brown, D. (1985). Uma História da Umbanda no Rio. Cadernos do ISER, (18), 9-42. 
Camargo, C. P. F. (1961). Kardecismo e Umbanda. Pioneira.

Carneiro, E. (1937). Negros Bantus. Civilização Brasileira.

Carneiro, E. (1948). Candomblés da Bahia. Publicações do Museu do Estado (Salvador), (8).

Cascudo, L. da C. (1951). Meleagro. Agir.

de Andrade, M. (1963). Música de Feitiçaria no Brasil. Martins.

do Rio, J. (Paulo Barreto). (1951). As Religiões do Rio. Simões.

Eduardo, O. da C. (1948). The Negro in Northern Brazil. University of Washington Press.

Fernandes, A. G. (1937). Xangôs do Nordeste. Civilização Brasileira.

Fernandes, A. G. (1938). O Folclore Mágico do Nordeste. Civilização Brasileira

Fry, P. (1982). Para Inglês Ver. Zahar.

Herskovits, M. (1943). The Southernmost Outposts of New World Africanisms. American Anthropologist, (45), 495-510. https://doi.org/10.1525/aa.1943.45.4.02a00020

Herskovits, M. (1955). The Social Organization of Candomblé. In H. Baldus (ed.), Anais do XXXI Congresso Internacional de Americanistas (pp. 505-532). Anhembi.

Herskovits, M. (1966). Some Economic Aspects of the Afrobahian Candomblé. In F. S. Herskovits (ed.), The New World Negro (pp. 248-265). University of Indiana Press.

Kardec, A. (1857). Le Livre des Esprits. E. Dentu.

Leacock, S., \& Leacock, R. (1971). Spirits of the Deep. Doubleday.

Lewis, I. (1971). Ecstatic Religion. Penguin Books.

Lima, V. da C. (1977). A Família de Santo nos Candomblés Jeje-Nagô da Bahia. Universidade Federal da Bahia.

Motta, R. (1977). Renda, Emprego, Nutrição e Religião. Ciência \& Trópico, 5(2), 121-154.

Motta, R. (1982). Bandeira de Alairá: A festa de Xangô-São João e problemas do sincretismo. In C. E. Marcondes de Moura (ed.), Bandeira de Alairá: Outros Escritos sobre a Religião dos Orixás (pp. 1-12). Nobel.

Motta, R. (1984a). Cultos Populares e Fontes Alternativas de Renda. In R. Duarte (ed.), Emprego e Renda na Economia Informal da América Latina (pp. 179-186). Massangana.

Motta, R. (1984b). Meat and Feast: The Xangô Religion of Recife, Brazil [Tese de doutorado, Columbia University].

Motta, R. (2005). A Jurema do Recife: Religião Indo-Afro-Brasileira em Contexto Urbano. In B. Caiubi Labate \& S. L. Goulart (eds.), O Uso Ritual das Plantas de Poder (pp. 279300). Mercado das Letras.

Motta, R. (2015a). “De Nina a Juana: Representações da África e do Candomblé, 1896-1976. In S. Brandão \& N. D. de Andrade Cabral (eds.), História das Religiões no Brasil (vol. 7, pp. 21-54). Carpe Diem.

Motta, R. (2015b). Quarante Ans Après : Jean Duvignaud, Marvin Harris et le Xangô de Recife Anamnèse (9), 25-40. 
Motta, R. (2015c). Social Scientists and Disenchanters: Same Basic Themes of Brazilian Sociology of Religion. In A. J. Blasi \& G. Giordan (eds.), Sociologies of Religion: National Traditions (pp. 72-106). Brill.

Motta, R. (2017). Religion, Sociology, Domination, and Intolerance: A View from Brazil. International Journal of Latin American Religion, (1), 222-239. https://doi.org/10.1007/s41603017-0022-5

Motta, R., \& Siuda-Ambroziak, R. (2019). The Sacrifice, the Feast and the Power of the Priesthood in the Xangô Cult of Recife. Studia Religiologica, 51(4), 279-295. https://doi.org/10.4467/20844077SR.18.020.10151

Ortiz, R. (1975). Du Syncrétisme à la Synthèse : Umbanda, Une Religion Brésilienne. Archives de Sciences Sociales des Religions, (40), 89-97. https://doi.org/10.3406/assr.1975.1920

Pereira, N. (1979). A Casa das Minas. Vozes.

Pierson, D. (1945). Brancos e Pretos na Bahia. Nacional.

Pressel, E. (1973). Umbanda in São Paulo: Religious Innovation in a Developing Society. In E. Bourguignon (ed.), Religion, Altered States of Consciousness and Social Change (pp. 264-318). Ohio State University Press.

Ramos, A. (1940). O Negro Brasileiro. Civilização Brasileira.

Ribeiro, J. (1963). O Jogo dos Búzios e as Grandes Cerimônias Ocultas da Umbanda. Editora Espiritualista.

Ribeiro, R. (1952). Cultos Afro-Brasileiros do Recife. Instituto Joaquim Nabuco.

dos Santos, J. T. (1995). O dono da terra: O caboclo no Candomblé da Bahia. Sarahletras.

Turner, V. (1975). Symbolic Studies. Annual Review of Anthropology, (4), 145-162. https://doi.org/10.1146/annurev.an.04.100175.001045

Valente, W. (1955). Sincretismo Religioso Afro-Brasileiro. Nacional.

Vandezande, R. (1975). Catimbó: pesquisa exploratória sobre uma forma nordestina de religião mediúnica. Universidade Federal da Paraíba.

Verger, P. (1957). Notes sur le Culte des Orisa et des Vodoun. Mémoires de 1'IFAN, (51).

Wach, J. (1944). Sociology of Religion. University of Chicago Press.

Warren, D., Jr. (1970). Notes on the Historical Origins of Umbanda. Universitas (6-7), 155-163.

Weber, M. (1978). Economy and Society. University of California Press. 